DOI: $10.21767 / 2471-3082.100009$

\section{Axial Contour Alteration following Restorative Treatment: A Systematic Review}

\section{Abstract}

Purpose: This qualitative systematic review had two aims: (1) evaluation of the impact of restorative treatment on tooth contour, and (2) investigation of the effect of altered tooth contour on biological health.

Methods: An electronic search was conducted using PubMed (MEDLINE), Cochrane Library and Google Scholar. A combination of relevant key words was applied. The search was completed in October 2015 and was confined to peer-reviewed studies published in English.

Results: The initial search had disclosed a total of 1057 studies; however, after applying the inclusion criteria, only 12 studies were suitable for inclusion. The studies had revealed that the axial tooth contour is vulnerable to increasing following restorative treatment. The axial contour tends to increase gradually as the distance from the gingival margin increases. Still, the contour increase was within the anatomical range. There were signs that increased tooth contour was associated with negative biological consequences. However, a clear relationship between contour increase and the biological consequences was not apparent. There were indications that the observed negative consequences may be related to restorative variables such as plaque retentiveness and subgingival margin placement.

Conclusions: As the contour increase appears to be very likely to occur after restorative treatment, and the negative biological consequences cannot be solely attributed to the contour increase, it can be concluded that reasonable contour alteration is acceptable. The key factors that will reduce the negative consequences are cleansability and the maintenance of a healthy restoration-soft tissue relationship.

Keywords: Contour; Emergence; Profile; Prosthodontics; Dental restoration

\section{Jaafar Abduo \\ Melbourne Dental School, Melbourne University, 720 Swanston Street, Melbourne, Victoria, Australia}

\section{Corresponding author: Jaafar Abduo}

¡jaafar.abduo@unimelb.edu.au

Melbourne Dental School, Melbourne University, 720 Swanston Street, Melbourne, Victoria, Australia.

Tel: 0061-3-9035-8998

Fax: 0061-3-9341-1599

Citation: Abduo J, Axial Contour Alteration following Restorative Treatment: A Systematic Review. Periodon Prosthodon. 2016, 2:1.

\section{Introduction}

Naturally, teeth exhibit straight axial profile from the base of the gingival sulcus to the supragingival aspect of the clinical crown [1]. This relationship is believed to reduce plaque accumulation and enhance the cleansability [2]. Frequently, restorative treatment is planned to improve dental esthetics which can be achieved by altering tooth colour and morphology. The treatment mandates tooth surface reduction to provide adequate space for restorative material. The sufficient space will facilitate achieving properly contoured, durable and esthetic restoration. However, it is not uncommon for the tooth contour to be altered following the restorative treatment which can evoke negative biological sequelae such as dental caries and periodontal complications. Therefore, it has been recommended that whenever a tooth is restored, the restoration should blend harmoniously with the natural tooth contour $[1,2]$.

The literature presents three different methods for restoring the axial tooth contour: preserving the original tooth contour, undercontouring and over-contouring. Maintaining the original contour has been advocated to preserve a natural and physiological relationship between the tooth and the gingival tissues, which 
will not interfere with routine cleaning [1,2]. However, this method may restrict the final tooth shape modifications. Undercontouring has been suggested to facilitate the self-cleansing abilities of the gingival tissues [3-5]. Although this method has some merits, it is impractical as it may negatively influence the appearance, restoration material thickness and preparation invasiveness [4]. In some situations, the clinician can prescribe an over-contoured restoration if the planned restoration volume is greater than the initial tooth volume $[6,7]$. This method is advantageous in allowing significant esthetic improvement if dentition irregularities exist. However, there are concerns that the contour increase will evoke plaque retention and biological complications [2]. Therefore, it is desirable to investigate the implications of altered tooth contour on biological health. This systematic review aims to evaluate the impact of restorative treatment on axial tooth contour and assess the relationship between the altered axial tooth contour and biological health.

\section{Materials and Methods}

The electronic search was conducted through PubMed (MEDLINE), Cochrane Central Register of Combined Trials and Google Scholar. The search was completed in October 2015. Through the PubMed database, the Boolean operator was employed to combine the following key words: ("contour" OR "emergence profile" OR "axial surface") AND ("restoration" OR "crown" OR "prosthesis") NOT ("implant" OR "removable"). All the articles related to tooth contour were retrieved from the Cochrane Database. The Google Scholar search engine was used to retrieve relevant studies by combining the following terms: tooth contour, restoration contour and emergence profile. No publication year limit was applied. The search aimed to retrieve all the clinical, laboratory and animal studies that investigated the restoration effect on the contour and the biological consequences of the altered contour.

Three stages for selecting the relevant studies were followed: (1) studies selection according to the relevance of the title; (2) studies selection according to the abstract relevance; (3) full text analysis and application of predefined inclusion criteria (Table 1). After studies selection, additional relevant articles were searched manually through the bibliographies of the included studies.

Two categories of studies were considered for this review:

- Group I: Contour measurement studies. Where the study evaluates the contour alteration after the restorative treatment.

- Group II: Contour implications studies. Where the study investigates the effect of the altered contour on biological variables.

Table 1 Inclusion criteria.

$$
\text { English language study }
$$

Laboratory, clinical or animal study

Study on restored dentition

Direct restoration or fixed prosthesis

No implant or removable prosthesis

There is a well-defined control group or comparison group

\section{Results}

\section{Literature search}

A total of 1057 studies were retrieved after the initial search. After the analysis of titles, 990 studies were excluded. Additional 41 studies were excluded after reading the abstracts. Therefore, a total of 26 studies were suitable for full-text analysis. Following the application of the inclusion criteria, 10 studies were considered for inclusion. Manual searching through bibliography lists of the selected studies had identified an additional two studies. Thus, a total of 12 studies were analysed in this review.

\section{Description of studies}

From the selected papers, five studies fit in to Group I (Table 2), and nine studies fit in to Group II (Table 3). Four studies of Group I were clinical and based on actual treated patients [8-11], and one of them was a laboratory study [12]. From Group II, six studies were human studies $[8,11,13-16]$ and three studies were animal studies $[5,17,18]$.

In relation to Group I, the studies had evaluated the axial tooth contour alteration after full gold crowns, porcelain-fused to metal (PFM) crowns, direct composite resin veneer, indirect composite resin veneer, and ceramic veneer. All the measurements were executed on dental casts. The contour was evaluated by either comparing the treated tooth to an intact contralateral tooth or to its pre-treatment contour. Three forms of tooth contour parameters were evaluated: the width of the tooth, the emergence angle and post-treatment volume. The increased tooth width, increased emergence angle or greater volume indicated an increase in tooth contour. The implemented contour measurement methods were the dimensional measurement of tooth width [8], surface morphology $[10,12]$, and cross sectional analysis $[9,11]$. In addition, the relationship between the axial tooth contour alterations and the location on the tooth from the gingival margin was evaluated by some studies [10-12].

For Group II human studies, the contour alteration was either part of the actual treatment or purely experimental. When the contour alteration was part of the definitive treatment (gold, PFM, ceramic and acrylic full crowns, or partial crowns), the contour increase was evaluated and was related to the biological variables $[8,11]$. The experimental studies involved altering the tooth contour to a defined dimension by a temporary approach throughout the experiment duration [13-16]. These studies were distinguished with the short-term contour alterations. The contour alteration methods were PFM crowns, acrylic crowns, acrylic veneers and metal veneers.

Similar to Group I studies, the axial tooth contour was evaluated by measuring the tooth width and the emergence angle. In relation to the width, the increase of the applied contour increase was in the range of $0.18 \mathrm{~mm}$ to $0.5 \mathrm{~mm}$. One study had reduced the tooth width by $1 \mathrm{~mm}$ ( $0.5 \mathrm{~mm}$ per surface). The emergence angle ranged from normal contour $\left(0^{\circ}\right)$ up to an emergence angle of $40^{\circ}$. The level of contour alteration was subgingival, equigingival or supragingival. The evaluated biological variables were plaque quantity and quality, gingival index, probing depth, crevicular fluid, bleeding index, and clinical attachment level loss. 
Table 2 Summary of studies that evaluated the impact of restorative treatment on axial tooth contour.

\begin{tabular}{|c|c|c|c|c|c|}
\hline Study (year) & $\begin{array}{c}\text { Study } \\
\text { description }\end{array}$ & $\begin{array}{l}\text { Sample number } \\
\text { and description }\end{array}$ & Treatment & $\begin{array}{c}\text { Method of } \\
\text { measurements }\end{array}$ & Results \\
\hline Parkinson [8] & Clinical study & $\begin{array}{l}50 \text { teeth } \\
\text { Compared } \\
\text { to intact } \\
\text { contralateral } \\
\text { teeth }\end{array}$ & $\begin{array}{c}\text { Crowns } \\
-25 \text { gold crowns } \\
-25 \text { PFM crowns }\end{array}$ & $\begin{array}{l}\text { Tooth width } \\
\text { measurements }\end{array}$ & $\begin{array}{l}80 \% \text { of the crowns had a wider buccolingual } \\
\text { dimension than the contralateral teeth } \\
\text { The width increase was } 0.71 \mathrm{~mm} \text { for PFM crowns } \\
\text { and } 0.36 \mathrm{~mm} \text { for gold crowns }\end{array}$ \\
\hline $\begin{array}{c}\text { Meijering et al. } \\
{[10]}\end{array}$ & Clinical study & $\begin{array}{l}15 \text { maxillary } \\
\text { central incisors } \\
\text { Compared to the } \\
\text { pre-treatment } \\
\text { contour }\end{array}$ & $\begin{array}{l}\text { Veneers } \\
-5 \text { direct } \\
\text { composite } \\
\text { veneers } \\
-5 \text { indirect } \\
\text { composite } \\
\text { veneers } \\
-5 \text { ceramic } \\
\text { veneers }\end{array}$ & $\begin{array}{c}\text { Volumetric } \\
\text { measurements at } 3 \\
\text { vertical locations } \\
\text {-Cervical } \\
\text {-Middle } \\
\text {-Incisal edge }\end{array}$ & $\begin{array}{l}\begin{array}{l}\text { Greater dimension increase occurred incisally than } \\
\text { cervically }\end{array} \\
\text { At the cervical region, the tooth width was } \\
\text { minimally affected } \\
\text { At the middle region, } 60 \% \text { of the veneers were } \\
\text { wider than the pre-treatment contour } \\
\text { At the incisal edge, } 73 \% \text { of the veneers were wider } \\
\text { than the pre-treatment contour } \\
\text { The different restorative treatments had similar } \\
\text { effect on the contour }\end{array}$ \\
\hline Alhouri et al. [9] & Clinical study & $\begin{array}{l}55 \text { teeth } \\
\text { Compared } \\
\text { to intact } \\
\text { contralateral } \\
\text { teeth }\end{array}$ & $\begin{array}{l}\text { Crowns } \\
-32 \text { anterior } \\
\text { crowns } \\
-23 \text { posterior } \\
\text { crowns }\end{array}$ & $\begin{array}{l}\text { Analysis of } \\
\text { cross sections } \\
\text { and curvature } \\
\text { measurements } \\
\text { Straight profile } \\
\text { was interpreted as } \\
\text { under-contoured } \\
\text { while curved profile } \\
\text { was interpreted as } \\
\text { over-contoured }\end{array}$ & $\begin{array}{l}\text { Most of the full crowns had similar curvature or } \\
\text { slight tendency to have less curvature } \\
\text { The buccal contour of most of the posterior crowns } \\
\text { was minimally affected } \\
\text { The buccal contour of half of the anterior crowns } \\
\text { was similar to the contralateral teeth } \\
\text { The lingual contour of half of the posterior crowns } \\
\text { was similar to the contralateral teeth } \\
\text { Lingual contour of half of the anterior crowns was } \\
\text { under-contoured }\end{array}$ \\
\hline $\begin{array}{c}\text { Yotnuengnit et } \\
\text { al. [11] }\end{array}$ & Clinical study & $\begin{array}{l}50 \text { anterior teeth } \\
\text { Compared } \\
\text { to intact } \\
\text { contralateral } \\
\text { teeth }\end{array}$ & $\begin{array}{c}\text { Crowns } \\
-88 \% \text { PFM } \\
\text { crowns } \\
-4 \% \text { porcelain } \\
\text { crowns } \\
-2 \% \text { partial } \\
\text { veneer crowns }\end{array}$ & $\begin{array}{l}\text { Analysis of cross } \\
\text { sections and } \\
\text { measurement of } \\
\text { subgingival and } \\
\text { supragingival } \\
\text { emergence angle }\end{array}$ & $\begin{array}{l}\text { Overall, the crowns had greater emergence angle } \\
\text { than the contralateral teeth } \\
\text { The recorded mean emergence angles were } \\
\text {-Supragingival emergence was } 11.1^{\circ} \text { for natural } \\
\text { teeth, and } 14.2^{\circ} \text { for restored teeth. The difference is } \\
\text { not significant } \\
\text {-Subginigval emergence was } 9.9^{\circ} \text { for natural teeth, } \\
\text { and } 17.1^{\circ} \text { for restored teeth. The difference is } \\
\text { significant }\end{array}$ \\
\hline $\begin{array}{c}\text { Vasconcelos et } \\
\text { al. [12] }\end{array}$ & Laboratory study & $\begin{array}{c}24 \text { maxillary } \\
\text { canines } \\
\text { Compared to the } \\
\text { pre-treatment } \\
\text { contour }\end{array}$ & $\begin{array}{c}\text { Indirect } \\
\text { composite } \\
\text { veneers by } \\
3 \text { different } \\
\text { technicians } \\
-12 \text { veneers with } \\
\text { no reference } \\
\text { tooth } \\
\text {-12 veneers with } \\
\text { reference tooth }\end{array}$ & $\begin{array}{l}\text { Tooth width } \\
\text { measurements in } \\
5 \text { vertical locations } \\
\text { from the gingival } \\
\text { margin } \\
-0 \mathrm{~mm} \\
-0.5 \mathrm{~mm} \\
-1 \mathrm{~mm} \\
-1.5 \mathrm{~mm} \\
-2 \mathrm{~mm}\end{array}$ & $\begin{array}{l}\text { All the veneers were over-contoured } \\
\text { None of the dental technicians could establish } \\
\text { the original contour, even with the presence of a } \\
\text { reference intact tooth } \\
\text { The contour increased gradually as the distance } \\
\text { from the gingival margin increases } \\
\text { The average contour increase for each vertical } \\
\text { location was } \\
\text {-Level } 0.0 \mathrm{~mm}: 0.31 \mathrm{~mm} \\
\text {-Level } 0.5 \mathrm{~mm}: 0.37 \mathrm{~mm} \\
\text {-Level } 1 \mathrm{~mm}: 0.43 \mathrm{~mm} \\
\text {-Level } 1.5 \mathrm{~mm}: 0.45 \mathrm{~mm} \\
\text {-Level } 2 \mathrm{~mm}: 0.47 \mathrm{~mm}\end{array}$ \\
\hline
\end{tabular}


Table 3 Summary of studies that evaluated the impact of tooth contour alteration on biological variables.

\begin{tabular}{|c|c|c|c|c|c|}
\hline Study (year) & $\begin{array}{l}\text { Study description } \\
\text { and duration }\end{array}$ & $\begin{array}{l}\text { Sample number } \\
\text { and description }\end{array}$ & $\begin{array}{l}\text { Contour alteration } \\
\text { method and magnitude }\end{array}$ & $\begin{array}{l}\text { Evaluation } \\
\text { method }\end{array}$ & Results \\
\hline \multicolumn{6}{|c|}{ Human studies } \\
\hline $\begin{array}{c}\text { Parkinson } \\
{[8]}\end{array}$ & $\begin{array}{l}\text { Clinical study of } \\
\text { restored teeth } \\
\text { Non-specified } \\
\text { duration of } \\
\text { restoration service }\end{array}$ & $\begin{array}{l}\text { } 50 \text { teeth } \\
\text { Compared to intact } \\
\text { contralateral teeth }\end{array}$ & $\begin{array}{l}\text { Crowns } \\
-25 \text { gold crowns }(0.36 \\
\text { mm width increase) } \\
-25 \text { PFM crowns }(0.71 \\
\text { mm width increase) }\end{array}$ & Plaque index & $\begin{array}{l}\text { Significantly greater plaque accumulation } \\
\text { around the restored teeth than intact teeth } \\
\text { There was no significant difference in plaque } \\
\text { index between gold and PFM crowns }\end{array}$ \\
\hline $\begin{array}{c}\text { Sackett and } \\
\text { Gildenhuys } \\
{[13]}\end{array}$ & $\begin{array}{l}\text { Clinical study of } \\
\text { experimental } \\
\text { modifications of } \\
\text { tooth contour } \\
\text { Duration: } 42-49 \text { days }\end{array}$ & $\begin{array}{l}42 \text { first premolar } \\
\text { teeth } \\
\text { Compared to intact } \\
\text { adjacent teeth }\end{array}$ & $\begin{array}{c}\text { Processed acrylic veneers } \\
\text { located supragingivally } \\
\text { (1 mm buccal contour } \\
\text { increase) }\end{array}$ & $\begin{array}{l}\text { Gingival status } \\
\text { Pocket depth } \\
\text { Gingival } \\
\text { crevicular fluid }\end{array}$ & $\begin{array}{l}\text { The evaluated variables were significantly } \\
\text { affected after increasing the contour } \\
59 \% \text { of mandibular sites and } 70 \% \text { of } \\
\text { maxillary sites showed signs of degradation, } \\
\text { inflammation and gingival tissues } \\
\text { morphological alterations than control sites } \\
59 \% \text { of mandibular sites and } 50 \% \text { of } \\
\text { maxillary sites showed greater production of } \\
\text { gingival crevicular fluid than control sites }\end{array}$ \\
\hline $\begin{array}{c}\text { Ehrlich and } \\
\text { Hochman } \\
{[14]}\end{array}$ & $\begin{array}{l}\text { Clinical study of } \\
\text { experimental } \\
\text { modifications of } \\
\text { tooth contour } \\
\text { Duration: } 4 \text { months }\end{array}$ & $\begin{array}{l}\text { Several teeth in } 4 \\
\text { patients } \\
\text { Compared the } \\
\text { effects of over- } \\
\text { contouring and } \\
\text { under-contouring }\end{array}$ & $\begin{array}{l}\text { Fixed acrylic partial } \\
\text { dentures with } \\
\text { supragingival margin } \\
\text {-Over-contouring (1 mm } \\
\text { width increase) } \\
\text {-Under-contouring (1 } \\
\text { mm width reduction) }\end{array}$ & $\begin{array}{l}\text { Tissue changes } \\
\text { and the gingival } \\
\text { margin reaction } \\
\text { in relation to } \\
\text { colour, size, } \\
\text { contour and } \\
\text { inflammation }\end{array}$ & $\begin{array}{l}\text { Significant clinical difference was not } \\
\text { observed between the two sides. The } \\
\text { response of the gingiva to the different } \\
\text { crown contours was clinically normal } \\
3 \text { of the } 4 \text { patients reported esthetic } \\
\text { difference } \\
\text { No difficulties in cleaning was noticed by any } \\
\text { of the patients }\end{array}$ \\
\hline $\begin{array}{l}\text { Creugers et } \\
\text { al. [15] }\end{array}$ & $\begin{array}{l}\text { Clinical study of } \\
\text { experimental } \\
\text { modifications of } \\
\text { tooth contour } \\
\text { Duration: } 10 \text { days for } \\
\text { each oral hygiene } \\
\text { protocol (one period } \\
\text { with home care, } \\
\text { one period with no } \\
\text { cleaning) }\end{array}$ & $\begin{array}{l}\text { } 20 \text { teeth } \\
\text { Compared to intact } \\
\text { contralateral teeth }\end{array}$ & $\begin{array}{c}\text { Resin bonded metal } \\
\text { wings located } \\
\text { supragingivally ( } 0.5 \mathrm{~mm} \\
\text { palatal contour increase) }\end{array}$ & $\begin{array}{l}\text { Plaque index } \\
\text { Papillary bleeding } \\
\text { index }\end{array}$ & $\begin{array}{l}\text { In the cleaning period, there was minimal } \\
\text { difference in the plaque and bleeding } \\
\text { indices } \\
\text { In the no cleaning period, the plaque and } \\
\text { bleeding indices had increased for the } \\
\text { two groups. There was tendency for the } \\
\text { experimental group to show more increase } \\
\text { plaque and bleeding indices than the control } \\
\text { group }\end{array}$ \\
\hline $\begin{array}{l}\text { Sundh and } \\
\text { Kohler [16] }\end{array}$ & $\begin{array}{l}\text { Clinical study of } \\
\text { experimental } \\
\text { modifications of } \\
\text { tooth contour } \\
\text { Duration: } 9 \text { days for } \\
\text { each crown }\end{array}$ & $\begin{array}{l}7 \text { premolar teeth } \\
\text { Compared the } \\
\text { effects of different } \\
\text { crown contours }\end{array}$ & $\begin{array}{l}4 \text { PFM crown designs } \\
\text { with equigingival or } \\
\text { supragingival margins } \\
\text {-Natural emergence } \\
-10^{\circ} \text { contour increase } \\
-25^{\circ} \text { contour increase } \\
-40^{\circ} \text { contour increase }\end{array}$ & $\begin{array}{l}\text { Plaque quantity } \\
\text { and quality }\end{array}$ & $\begin{array}{c}\text { The experimental crowned teeth had less } \\
\text { plaque than the control teeth } \\
\text { There was no plaque quality difference } \\
\text { between the different groups }\end{array}$ \\
\hline
\end{tabular}




\begin{tabular}{|c|c|c|c|c|c|}
\hline $\begin{array}{c}\text { Yotnuengnit } \\
\text { et al. [11] }\end{array}$ & $\begin{array}{l}\text { Clinical study of } \\
\text { restored teeth } \\
\text { Duration: about } 30 \\
\text { months of restoration } \\
\text { service }\end{array}$ & $\begin{array}{l}50 \text { anterior teeth } \\
\text { Compared to intact } \\
\text { contralateral teeth }\end{array}$ & $\begin{array}{l}\text { Crowns with subgingival } \\
\text { margins } \\
-88 \% \text { PFM crowns } \\
-4 \% \text { porcelain crowns } \\
-6 \% \text { acrylic crowns } \\
-2 \% \text { partial veneer } \\
\text { crowns } \\
\text { Mean emergence angle } \\
\text {-Natural teeth (11.1 } \\
\text { supragingival emergence, } \\
9.9^{\circ} \text { subginigval } \\
\text { emergence) } \\
\text {-Restored teeth (14.2 }{ }^{\circ} \\
\text { supragingival emergence, } \\
17.1^{\circ} \text { subgingival } \\
\text { emergence) }\end{array}$ & $\begin{array}{l}\text { Plaque index } \\
\text { Gingival index } \\
\text { Pocket depth } \\
\text { Clinical } \\
\text { attachment loss }\end{array}$ & 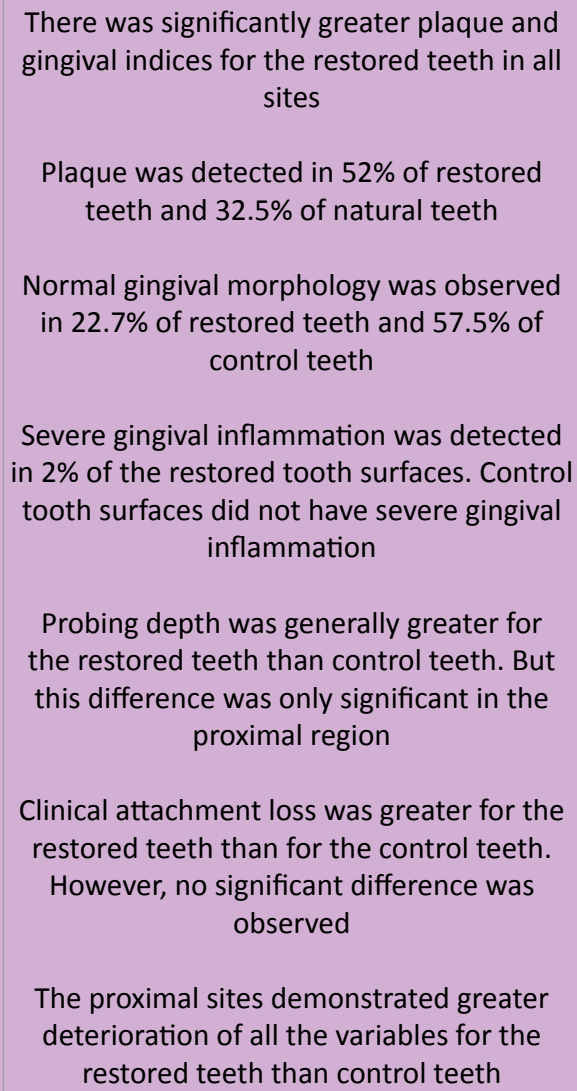 \\
\hline \multicolumn{6}{|c|}{ Animal studies } \\
\hline Perel [5] & $\begin{array}{l}\text { Animal study of } \\
\text { experimental } \\
\text { modifications of } \\
\text { tooth contour } \\
\text { Duration: } 1-9 \text { weeks }\end{array}$ & $\begin{array}{l}\text { Mandibular teeth of } \\
\qquad 6 \text { dogs } \\
\text { Compared the } \\
\text { effects of over- } \\
\text { contouring and } \\
\text { under-contouring }\end{array}$ & $\begin{array}{c}\text {-Contour increase by } \\
\text { supragingival cervical } \\
\text { acrylic resin restoration } \\
\text { ( } 2 \text { mm contour increase) } \\
\text {-Contour reduction } \\
\text { by axial convexity } \\
\text { elimination }\end{array}$ & $\begin{array}{l}\text { Clinical gingival } \\
\text { evaluation in } \\
\text { relation colour, } \\
\text { shape and } \\
\text { bleeding on } \\
\text { probing } \\
\text { Histological } \\
\text { evaluation }\end{array}$ & $\begin{array}{l}\text { Gingival deterioration was observed } \\
\text { after increasing the contour (gingival } \\
\text { swelling, redness, hypertrophied gingiva, } \\
\text { tendency to bleed after probing and plaque } \\
\text { accumulation) } \\
\text { Reducing the contour did not have negative } \\
\text { consequences on the gingiva } \\
\text { Histological evaluation revealed increase } \\
\text { of inflammatory cells and engorgement of } \\
\text { blood vessels in the gingival margin in the } \\
\text { over-contoured sites }\end{array}$ \\
\hline $\begin{array}{c}\text { Kohal et al. } \\
\text { [17] }\end{array}$ & $\begin{array}{l}\text { Animal study of } \\
\text { experimental } \\
\text { modifications of } \\
\text { tooth contour } \\
\text { Duration: } 5 \text { months }\end{array}$ & $\begin{array}{c}\text { Second and third } \\
\text { premolars in three } \\
\text { quadrants of } 4 \text { dogs } \\
\text { Compared to the } \\
\text { intact teeth of the } \\
\text { last quadrant }\end{array}$ & $\begin{array}{l}\text { Gold crowns with } \\
\text { subgingival margins } \\
\text {-Natural emergence } \\
-30^{\circ} \text { contour increase } \\
-50^{\circ} \text { contour increase }\end{array}$ & $\begin{array}{l}\text { Plaque index } \\
\text { Gingival index } \\
\text { Gingival } \\
\text { crevicular fluid } \\
\text { Pocket depth } \\
\text { Clinical } \\
\text { attachment loss }\end{array}$ & $\begin{array}{l}\text { Over-contouring had negatively influenced } \\
\text { the evaluated parameters } \\
\text { Plaque index, gingival index, gingival } \\
\text { crevicular fluid and probing depth had } \\
\text { increased for } 30^{\circ} \text { and } 50^{\circ} \text { emergence groups. } \\
\text { Minimal alterations were observed for } \\
\text { control and normal contour groups } \\
\text { There was minimal difference between } 30^{\circ} \\
\text { and } 50^{\circ} \text { emergence groups, and between } \\
\text { control and normal contour groups } \\
\text { Clinical attachment level tends to decrease } \\
\text { over the experiment period for all the } \\
\text { restored teeth. The control group showed a } \\
\text { stable clinical attachment level }\end{array}$ \\
\hline
\end{tabular}




\begin{tabular}{|c|c|c|c|c|c|}
\hline $\begin{array}{c}\text { Kohal et al. } \\
\text { [18] }\end{array}$ & $\begin{array}{l}\text { Animal study of } \\
\text { experimental } \\
\text { modifications of } \\
\text { tooth contour } \\
\text { Duration: } 5 \text { months }\end{array}$ & $\begin{array}{l}2^{\text {nd }} \text { and } 3^{\text {rd }} \\
\text { premolars in three } \\
\text { quadrants of } 4 \text { dogs } \\
\text { Compared to the } \\
\text { intact teeth of the } \\
\text { last quadrant }\end{array}$ & $\begin{array}{l}\text { Gold crowns with } \\
\text { subgingival margins } \\
\text { - Natural emergence } \\
-30^{\circ} \text { contour increase } \\
-50^{\circ} \text { contour increase }\end{array}$ & $\begin{array}{l}\text { Microbiological } \\
\text { analysis }\end{array}$ & $\begin{array}{l}\text { The contour had minimal effect on the } \\
\text { bacterial composition } \\
\text { No major differences existed between the } \\
\text { contour, normal contour and } 50^{\circ} \text { emergence } \\
\text { groups. The } 30^{\circ} \text { emergence group had } 3 \\
\text { times the amount of total bacterial count } \\
\text { Overall, no trend was observed regarding } \\
\text { the pathological bacterial species. The } \\
\text { means of microorganisms number and the } \\
\text { means of total bacterial load for a given } \\
\text { organism were higher in the } 30^{\circ} \text { and } 50^{\circ} \\
\text { emergence groups than in the control and } \\
\text { normal contour groups }\end{array}$ \\
\hline
\end{tabular}

The three animal studies were experimental in nature. The teeth contour was altered by resin restoration or crowning with gold crowns. The contour was increased by widening the tooth surface by $2 \mathrm{~mm}$ or increasing the emergence profile angle $\left(0-50^{\circ}\right)$. One study altered the contour supragingivally [5] while the other two studies subgingivally $[17,18]$. In addition, one study had reduced the contour by eliminating the tooth axial convexity [5]. The evaluated biological variables were plaque quality and quantity, gingival index, probing depth, crevicular fluid and clinical attachment level loss. One study had conducted microscopic examination of the gingival tissues [5].

\section{Studies' outcome}

Group I: All the included studies confirmed that the axial tooth contour is vulnerable to modifications following restorative treatment. Most of the alterations tended to be an increase of the contour $[8,10-12]$. Only one study reported a reduction of the contour following restorative treatment [9]. However, this study had primarily evaluated the convexity of the surface rather than the contour dimensions. Parkinson had found that $80 \%$ of the treated teeth with crowns were over-contoured [8]. Depending on the location on the tooth, up to $73 \%$ of the veneers were reported by Meijering et al. to have a contour increase [10]. Yotnuengnit et al. had found the emergence angle of the restored teeth was likely to be greater than the control teeth [11]. Vasconcelos et al. had found that $100 \%$ of the teeth had an increase in the contour following restorations [12]. This was the case even when the technicians had access to the reference tooth contour.

Magnitude of contour increase: Parkinson had recorded that the magnitude of contour increase was in the range of 0.36 to $0.71 \mathrm{~mm}$ (0.18 to $0.36 \mathrm{~mm}$ per surface) [8]. Yotnuengnit et al. had shown the emergence angle to increase by a range of $3.1^{\circ}$ to $7.2^{\circ}$ [11]. Depending on the vertical location on the restored tooth, Vasconcelos et al. had reported that the increase was in the range of 0.31 to $0.47 \mathrm{~mm}$ [12].

Effect of restoration type: From the limited amount of evidences, the effect of the different restoration type on the contour is not very clear. Parkinson found the PFM crowns had double the contour increase than the full gold crowns [8]. Meijering et al. had found that there was no difference in the magnitude of contour alteration after restoring the tooth with ceramic veneer, direct composite veneer or indirect composite veneer [10].

Location effect on the contour: there is a trend for the tooth surface that is furthest away from the gingival tissues to experience greater contour increase. According to Meijering et al. the incisal width was more affected from over-contouring while the cervical width is very identical to the original tooth contour [10]. Similarly, Vasconcelos et al. had observed a consistent increase of the contour as the distance from the gingival margin increases [12]. On the other hand, Yotnuengnit et al. had found the emergence angle was greater for the subginigival profile than the supragingival profile [11].

Group II: Some of the studies reported a direct relationship between the contour increase and biological complications $[8,11,13,15]$ while others did not $[14,16]$. The studies on permanent restorations consistently reported a negative biological relationship with dental restoration. Parkinson had found a greater plaque index associated with crowns that had increased contour [8]. Likewise, Yotnuengnit et al. had confirmed this relationship [11]. Although the actual increase in contour is minimal (about $7^{\circ}$ ), there was more detectable plaque around the restored teeth [11]. On the contrary, the short-term studies provided conflicting findings. In a cross-mouth study by Ehlirich and Hochman, under-contouring or over-contouring by $1 \mathrm{~mm}$ alteration of tooth width was not associated with significant clinical changes in the healthy gingiva [14]. Thus they concluded that healthy gingival tissues can tolerate contour changes. This was supported by Sundh and Kohler, who found that the increase in crown contour was not associated with greater plaque accumulation over a short period [16]. Further, the plaque quality was similar between the restored and intact teeth. On the other hand, Sacket and Gildenhuys had observed deleterious effects on gingival parameters after increasing the contour of premolars by augmenting the buccal contour with $1 \mathrm{~mm}$ thick acrylic veneer [13]. Similarly, after bonding $0.5 \mathrm{~mm}$ thick metal veneers on the palatal surfaces of central and lateral incisors, Creuger et al. had observed over-contouring was associated with greater plaque retention [15].

The animal studies confirmed that biological consequences 
may develop after altering the tooth contour for dogs. Perel had increased and decreased the contour of dogs' teeth and found that reducing the tooth contour was not associated with negative consequences [5]. However, increasing the contour was significantly related to negative consequences [5]. The other two studies were published by the same research group $[17,18]$. After increasing the contour, the periodontal parameters were negatively affected [17]. However, according to the microbiological analysis, there was a minimal effect of the contour on bacterial composition [18]. In addition to restoration contour, there are additional factors that are likely to contribute to the outcome of the included studies, such as plaque retentiveness and the restoration margin location.

Effect of plaque retentiveness: It appears that plaque retentive methods of altering the contour exacerbate the negative biological outcome. For example, the studies that had provided an abrupt contour increase found negative consequences $[5,13,15]$. The abrupt contour alteration is responsible for hindering the physiological cleaning methods. Some authors anticipated that material selection has a biological impact, where acrylic resin is more plaque retentive $[5,13]$. The effect of plaque accumulation is further supported by the observation that the lack of routine cleaning significantly increases the biological complications $[5,15]$.

Effect of restoration margin location: The margin location was found to be a main contributing variable to the observed outcome. For example, the studies that had increased the contour supragingivally or equigingivally, with a restoration that is not plaque retentive, did not confirm the negative biological consequences $[14,16]$. On the other hand, the studies that had altered the contour by subgingival restorations had found negative outcomes [11,17]. In fact, Yotnuengnit et al. had found that even with a minimal contour increase, the subgingival over-contouring was associated with more negative biological consequences [11]. Therefore, given that the magnitude of contour increase is minimal, the negative consequences may be related to tissue reaction to prosthesis or subgingival placement $[8,11]$.

\section{Discussion}

This systematic review confirms that restoring teeth with direct or indirect restorations can easily change the contour [8,12], mostly in the form of increasing the contour. This could be attributed to several factors such as tooth preparation effect, contour increase for durability and esthetics. In addition, the likelihood of altering the tooth contour indicates the difficulties for the clinician and technician in achieving the exact pre-treatment contour $[10,12]$. The magnitude of contour increase appears to be influenced by several factors such as the type of restoration and location on the tooth. Further, there are indications that increasing the contour of the restored teeth might negatively influence the periodontal health.

The magnitude of tooth contour alteration could be attributed to the amount of tooth preparation and the requirements of esthetic improvements. In order to restore natural contour with dental restoration, a sufficient amount of tooth structure should be removed. For example, crown restoration margin width for an esthetic crown (PFM or all ceramic) ranges from 1-1.2 $\mathrm{mm}$ [3]; therefore, a significant portion of tooth structure will irreversibly be prepared, which can lead to a loss of up to $30 \%$ to $70 \%$ of natural tooth structure [19]. However, extensive tooth preparation will render the tooth more susceptible to endodontic complications and weakening of tooth structure [3]. From the conservative perspective, the clinician might opt to reduce the amount of preparation. As a result, the technician may restore the tooth to natural contour but with compromising material thickness and esthetic quality. Alternatively, the restorative materials can be used in their recommended thickness thereby overbuilding the crown, thus increasing its emergence profile $[3,20]$. In accordance with this explanation, Parkinson had found gold crowns were associated with half the contour increase of the PFM crowns [8]. This also coincides with the amount of axial reduction required for gold crowns which is about half the amount required for PFM crowns [3]. In addition, in some situations, the deliberate increase of tooth contour, mainly anterior teeth, is advantageous in the improvement of dental esthetics. From the morphological perspective, altering the anterior tooth contour can restore the width, height, width-to-height ratio, and tooth natural alignment $[21,22]$.

Since the studies that evaluated the contour increase along the axial surface consistently reported a regular increase of the contour as the distance increases from the gingival margins $[10,12]$, it could be speculated that the contour increase had occurred gradually. One study found subgingival contour is slightly greater emergence angle than supragingival contour [11]. However, this is not necessarily contradicting the observation of the other studies, as it reflects the orientation of the axial surface rather than the width of the contour. Nevertheless, this gradual contour increase is different from an abrupt increase or an overhanging contour, and might not necessarily support plaque retention, as shown by some of the Group II studies [5,13,15]. In general, it appears from the included studies, that a contour increase that provided a smooth increase of the contour, at least in the short-term, did not indicate a pronounced increase in biological complications $[14,16]$. On the other hand, the studies that provided more plaque retentive design by abrupt contour increase had found a negative impact $[5,13,15]$. This is anticipated to be due to hindering the physiologic cleaning by lip, tongue or food chewing $[13,15]$. This is further supported by Perel who found no biological impact after under-contouring the teeth by removing the tooth convexity [5]. Therefore, it is evident that the studies that had increased the contour by a non-cleansable design, found negative consequences on periodontal health.

Interestingly, Vasconcelos et al. had found that even if the anatomical reference tooth was presented to the dental technicians, it was difficult to mimic the original contour, and over-contouring was still observable [12]. It is likely this is due to inevitable contour variation introduced from human intervention and material manipulation [12]. This indicates that although the operator may aim to achieve a specific contour or morphology, by pre-treatment or wax-up models, a precise contour is not always possible. Nevertheless, it is also possible that the slight 
difference in the contour is not necessarily clinically significant. In the future, greater precision of tooth contouring might become achievable with the implementation of digital technologies that reduce the reliance of human intervention and control materials manipulation [23].

In relation to the magnitude increase, although the studies had detected a contour increase, this increase was still within the recommendation of many authors. For example, the maximal increase hardly exceeded $0.5 \mathrm{~mm}[8,12]$, which is still within the range of natural teeth anatomy [24]. Similarly, in relation to the emergence angle, the natural teeth have an emergence angle of about $15^{\circ}$ from the cement-enamel junction $[25,26]$, which is similar to the observation by Yotnuengnit et al. for natural $\left(9.9^{\circ}-11.1^{\circ}\right)$ and even for restored teeth $\left(14.2^{\circ}-17.1^{\circ}\right)$ [11]. Further, it is important to indicate that although many studies in Group II found increased negative consequences after increasing the contour to these dimensions $[8,11,17]$, a few studies did not indicate a clear relationship with biological problems, even if the contour width was significantly increased $[14,16]$. Moreover, if negative consequences occur, they may not be fully attributed to contour alterations. Part of the variation within Group II studies can be related to the inevitable differences in the studies' design and duration, and to the restorative procedure effect on periodontal health. Several researches discussed restorative variables that can influence periodontal health, such as restoration margin location. Subgingivally crown margin placement has been confirmed to be associated with gingival inflammation, loss of periodontal support, pocket development and gingival recession [27-29]. This could be due to preparation trauma, constant irritation, microbial biofilm formation close to the gingiva, a likelihood of violating the biologic width, and difficulties in maintaining a good level of cleanliness at the margin. The inevitable roughness of restoration-tooth junction may facilitate microbial adhesion and plaque accumulation. On the other hand, supragingival margins have been found to be related to the lower gingival scores in comparison with subgingival margins $[27,30,31]$. This may explain the observation of the studies included in this systematic review, as the ones that had increased the contour by subgingivally placed restoration found negative biological consequences $[11,17]$, while the ones that kept the restorations supragingivally did not find a negative biological impact $[14,16]$.

This systematic review outlines the limitations of evidences in relation to the impact of restorative treatment on tooth contour and the impact of altered contour of the restored teeth. This is very clear in the limited participant number of several studies and the method of altering the contours. Although it appears from the included studies that there is an impact of increasing the contour of the restored teeth, much of the impact can be attributed to restorative factors such as the cleansability of the restoration and the gingiva-restoration relationship. Thus, it is difficult to attribute the observed negative biological consequences purely to the altered axial contour. Therefore, more studies that can isolate the effect of each restorative variable are desirable. In addition, the clinical significance of the observed negative consequences is yet to be determined $[17,18]$. According to the currently available evidences, it can be envisaged that reasonable over-contouring can be provided, as long as the restoration is cleansable and does not violate the biologic width.

\section{Conclusion}

Within the limitations of this review, it can be concluded that axial contour alteration is inevitable after restorative treatment. The alterations were mainly in the form of increasing the contour. Contour alteration appears to be associated with negative biological consequences. However, much of the negative consequences appear to be exacerbated by the restorative procedure instead of purely from the increased contour. Reasonable contour alteration can be considered as part of the treatment. However, it might be beneficial to keep it minimal, without plaque retentive features and without violation of the biologic width. 


\section{References}

1 Croll BM (1989) Emergence profiles in natural tooth contour. Part I: Photographic observations. J Prosthet Dent 62: 4-10.

2 Becker CM, Kaldahl WB (1981) Current theories of crown contour, margin placement, and pontic design. J Prosthet Dent 45: 268-277.

3 Goodacre CJ, Campagni WV, Aquilino SA (2001) Tooth preparations for complete crowns: an art form based on scientific principles. J Prosthet Dent 85: 363-376.

4 Tjan AH, Freed H, Miller GD (1980) Current controversies in axial contour design. J Prosthet Dent 44: 536-540.

5 Perel ML (1971) Axial crown contours. J Prosthet Dent 25: 642-649.

6 Magne P, Belser UC (2004) Novel porcelain laminate preparation approach driven by a diagnostic mock-up. J Esthet Restor Dent 16: 7-16.

7 Magne P, Douglas WH (1999) Additive contour of porcelain veneers: a key element in enamel preservation, adhesion, and esthetics for aging dentition. J Adhes Dent 1: 81-92.

8 Parkinson CF (1976) Excessive crown contours facilitate endemic plaque niches. J Prosthet Dent 35: 424-429.

9 Alhouri N, Watts DC, McCord JF, Smith PW (2004) Mathematical analysis of tooth and restoration contour using image analysis. Dent Mater 20: 893-899.

10 Meijering AC, Peters MC, DeLong R, Pintado MR, Creugers NH (1998) Dimensional changes during veneering procedures on discoloured teeth. J Dent 26: 569-576.

11 Yotnuengnit $B$, Yotnuengnit $P$, Laohapand $P$, Athipanyakom S (2008) Emergence angles in natural anterior teeth: influence on periodontal status. Quintessence Int 39: 126-133.

12 Vasconcelos FS, Neves AC, Silva-Concilio LR, Cunha LG, Rode Sde M (2009) Influence of anatomic reference on the buccal contour of prosthetic crowns. Braz Oral Res 23: 230-235.

13 Sackett BP, Gildenhuys RR (1976) The effect of axial crown overcontour on adolescents. J Periodontol 47: 320-323.

14 Ehrlich J, Hochman N (1980) Alterations on crown contour effect on gingival health in man. J Prosthet Dent 44: 523-525.

15 Creugers NH, Snoek PA, Vogels AL (1988) Overcontouring in resinbonded prostheses: plaque accumulation and gingival health. J Prosthet Dent 59: 17-21.
16 Sundh B, Kohler B (2002) An in vivo study of the impact of different emergence profiles of procera titanium crowns on quantity and quality of plaque. Int J Prosthodont 15: 457-460.

17 Kohal RJ, Gerds T, Strub JR (2003) Effect of different crown contours on periodontal health in dogs. Clinical results. J Dent 31: 407-413.

18 Kohal RJ, Pelz K, Strub JR (2004) Effect of different crown contours on periodontal health in dogs. Microbiological results. J Dent 32: 153-159.

19 Hancocks S (2011) The ethics of cosmetics. Br Dent J 211: 501.

20 Seymour KG, Samarawickrama DY, Lynch EJ (1999) Metal ceramic crowns a review of tooth preparation. Eur J Prosthodont Restor Dent 7: 79-84.

21 Raj V (2013) Esthetic paradigms in the interdisciplinary management of maxillary anterior dentition-a review. J Esthet Restor Dent 25: 295-304.

22 Gillen RJ, Schwartz RS, Hilton TJ, Evans DB (1994) An analysis of selected normative tooth proportions. Int J Prosthodont 7: 410-417.

23 Abduo J, Lyons K, Bennamoun M (2014) Trends in computer-aided manufacturing in prosthodontics: a review of the available streams. Int J Dent pp: 1-16.

24 Burch JG, Miller JB (1973) Evaluating crown contours of a wax pattern. J Prosthet Dent 30:454-458.

25 Du JK, Li HY, Wu JH, Lee HE, Wang CH (2011) Emergence angles of the cementoenamel junction in natural maxillary anterior teeth. J Esthet Restor Dent 23: 362-369.

26 Croll BM (1990) Emergence profiles in natural tooth contour. Part II: Clinical considerations. J Prosthet Dent 63: 374-379.

27 Silness J (1970) Periodontal conditions in patients treated with dental bridges. 3 . The relationship between the location of the crown margin and the periodontal condition. J Periodontal Res 5: 225-229.

28 Lang NP (1995) Periodontal considerations in prosthetic dentistry. Periodontol 2000 9: 118-131.

29 Flores-de-Jacoby L, Zafiropoulos GG, Ciancio S (1989) Effect of crown margin location on plaque and periodontal health. Int J Periodontics Restorative Dent 9: 197-205.

30 Bergman B, Hugoson A, Olsson CO (1971) Periodontal and prosthetic conditions in patients treated with removable partial dentures and artificial crowns. A longitudinal two-year study. Acta Odontol Scand 29: 621-638.

31 Silness J (1980) Fixed prosthodontics and periodontal health. Dent Clin North Am 24: 317-329. 